Anna Banaszewska

Uniwersytet Wrocławski

\title{
PRAWO DO PRYWATNOŚCI WE WSPÓŁCZESNYM ŚWIECIE
}

Prawo do prywatności zajmuje szczególną pozycję we współczesnych katalogach wolności i praw. Zalicza się je do praw człowieka pierwszej generacji. Jest zagwarantowane w Powszechnej Deklaracji Praw Człowieka, Europejskiej Konwencji Praw Człowieka, Międzynarodowym Pakcie Praw Obywatelskich i Politycznych. W polskim porządku prawnym uregulowane zostało na poziomie konstytucyjnym w art. 47 Konstytucji, który gwarantuje każdemu prawo do ochrony prawnej życia prywatnego, rodzinnego, czci i dobrego imienia oraz do decydowania o swoim życiu osobistym. Swoje umocowanie aksjologiczne znajduje w przyrodzonej i niezbywalnej godności każdego człowieka. O ile nie ulega żadnej wątpliwości, że prawo do prywatności przysługuje każdej jednostce, to znaczne problemy powoduje określenie zakresu tego prawa, zwłaszcza we wciąż zmieniającej się rzeczywistości. W sytuacji gdy największe trudności wiążą się z samym ustaleniem obszaru prywatności, kluczowa staje się odpowiedź na pytanie, co właściwie jest przedmiotem ochrony prawa do prywatności. Jak stwierdził bowiem J.B. Young ,prywatność jest jak słoń - łatwiej ją rozpoznać, niż opisać."

M. Puwalski zwraca uwagę na fakt, że ,intuicyjnie wyczuwamy jakie działania mogą stanowić naruszenie prywatności, lecz nie jest nam łatwo precyzyjnie określić

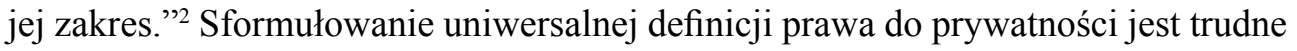
ze względu na jego szczególnie pojemny zakres przedmiotowy oraz brak precyzyjnego oddzielenia prywatności od innych prawnie chronionych wartości. To, jak obszerny jest zakres znaczeniowy prawa do prywatności, ilustruje J.C. Innes słowami: „decyzje w sprawie aborcji, konta komputerowe, seks, miłość, listy miłosne, decyzje antykoncepcyjne, ciało, dom, wyciągi bankowe - to jedynie początek listy heterogenicznych rzeczy, które są przedmiotem roszczeń z tytułu ,prywatności."”3 Prawo do poszanowania życia prywatnego wiąże się bowiem z dobrami osobistymi czło-

J.B. Young, Privacy, Chichester 1978, s. 3.

M. Puwalski, Prawo do prywatności osób publicznych, Toruń 2003, s. 13.

J.C. Innes, Privacy,Intimacy, and Isolation, New York-Oxford: Oxford University Press 1992, s. 6, [za:] K. Motyka, Prawo do prywatności i dylematy współczesnej ochrony praw człowieka, Lublin 2006, s. 139. 
wieka, integralnością człowieka, prawem do czci, prawem do własnego wizerunku i głosu, tajemnicą korespondencji, nienaruszalnością mieszkania, prawem do ochrony danych osobowych i danych dotyczących sytuacji majątkowej, sferą intymną, życiem rodzinnym i towarzyskim.

Kategoria prywatności (privacy) powstała na gruncie prawa anglosaskiego. Zaczęto o niej szeroko dyskutować w czasach dynamicznego rozwoju gazet $\mathrm{i}$ fotografii, pod koniec XIX w. Powszechnie przyjmuje się, że z prawem do prywatności mamy do czynienia od słynnego artykułu pt. The Right to Privacy autorstwa dwóch bostońskich prawników Samuela Warrena i Louisa Brandeisa opublikowanego w 1890 r. w „Harvard Law Review”. Uznali oni, że prywatność to prawo do bycia pozostawionym $\mathrm{w}$ spokoju (the right to be let alone), które chroni nienaruszalną osobowość człowieka.

Analizując piśmiennictwo dotyczące tej problematyki spotykamy dwa główne rodzaje definicji prawa do prywatności: wyliczające zachowania stanowiące naruszenie prawa do prywatności oraz koncentrujące się na określeniu obszarów podlegających ochronie. Niektórzy, napotykając trudności ze sformułowaniem definicji, podejmują próby ustalenia, czym prywatność nie jest. ${ }^{4}$ Niemała jest grupa badaczy opowiadająca się za teorią, że prawo do prywatności jest jedynie pochodną innych praw. ${ }^{5}$ Pojawiają się także głosy krytyczne, które odwołując się do szerokiego, nieokreślonego zakresu prawa do prywatności stwierdzają, że prawo do prywatności „znaczy już tak wiele, że nie znaczy nic.”6

Ramy tego opracowania nie pozwalają na dokładną analizę ewolucji sposobów ujmowania prywatności. Konieczne jednak jest przedstawienie różnych sposobów jego rozumienia znanych doktrynie. Szczegółową analizę koncepcji dotyczących prywatności dokonała J. Sieńczyło-Chlabicz, która przedstawia następujący podział:

1) prywatność jako prawo do pozostawienia w spokoju;

2) prywatność jako ochrona jednostki przed niechcianą ingerencją osób trzecich;

3) prywatność jako prawo do kontroli nad ujawnianiem informacji o życiu osobistym;

4) prywatność jako prawo do poszanowania tajemnicy prywatnej, tzn. nieujawniania sekretnych informacji o sobie osobom trzecim;

Por. L.R. BeVier, What Privacy Is Not, [w:] "Harvard Journal of Law \& Public Policy" 12/1989, s. 99.

J.J. Thomson, The Right to Privacy, [w:] "Philosophy and Public Affairs" 1975, no. 4, s.308 i n.; R. Posner, The Right to Privacy, [w:] "Georgia Law Review" 1978, no. 12, s. 3; E. Keynes, Liberty, Property, and Privacy. Toward a Jurisprudence of Substantive Due Process, University Park 1996, s. 3, [za:] J. Braciak, Prawo do prywatności, Warszawa 2004, s. 37.

6 Por. K. Motyka, Prawo do prywatności i dylematy współczesnej ochrony praw człowieka, Lublin 2006, s. 138. 
5) prywatność jako prawo do poszanowania intymności. ${ }^{7}$

Należy także wspomnieć o koncepcji prywatności jako prawa do swobodnego podejmowania decyzji o wszelkich aspektach naszego życia, określanej mianem decisonal privacy. Dotyczy ona w szczególności wolności wyboru sposobu życia, kwestii światopoglądowych, decydowania o sposobie wychowywania dzieci i decydowania o swoim ciele i akcentuje kwestie związane z prokreacją, antykoncepcją, aborcją. ${ }^{8}$

Próżno by szukać precyzyjnej definicji pojęcia prywatności w systemach prawnych poszczególnych państw. Również orzecznictwo nie udziela wyczerpującej odpowiedzi na pytanie o zakres prawa do prywatności. Jednakże to dzięki analizie orzecznictwa organów międzynarodowej ochrony praw człowieka ustalić możemy katalog działań stanowiących naruszenie prawa do poszanowania życia prywatnego oraz określić sfery podlegające ochronie. Dzięki bogatemu orzecznictwu Europejskiego Trybunału Praw Człowieka odnoszącemu się do art. 8 Europejskiej Konwencji Praw Człowieka i Podstawowych Wolności, w którym sformułowane zostały ogólne twierdzenia, precyzujące istotę prawa do poszanowania życia prywatnego i rodzinnego, możemy określić, jakie elementy składają się na pojęcie prawa do prywatności. Podkreślić jednak należy, iż sam Trybunał stwierdził, iż pojęcie „życia prywatnego" jest na tyle szerokim terminem, że nie daje się on wyczerpująco zdefiniować, ${ }^{9}$ choć celowa jest jego szeroka interpretacja. ${ }^{10}$

Prawo do poszanowania prywatności, mimo że jest wartością powszechnie chronioną, nie podlega jednocześnie ochronie absolutnej. Przesłanki usprawiedliwiające ingerencję w korzystanie $\mathrm{z}$ tego prawa przez władzę publiczną określa art. 8 ust. 2 Konwencji, zgodnie z którym „niedopuszczalna jest ingerencja władzy publicznej w korzystanie $\mathrm{z}$ tego prawa, $\mathrm{z}$ wyjątkiem przypadków przewidzianych przez ustawę i koniecznych w demokratycznym społeczeństwie z uwagi na bezpieczeństwo państwowe, bezpieczeństwo publiczne lub dobrobyt gospodarczy kraju, ochronę porządku i zapobieganie przestępstwom, ochronę zdrowia i moralności lub ochronę praw i wolności innych osób.” Wedle orzecznictwa Trybunału ,pojęcie konieczności oznacza, że ingerencja państwa odpowiada pilnej potrzebie społecznej oraz (...) jest proporcjonalna do uzasadnionego prawnie celu, który ma być zrealizowany."11 Również Trybunał Konstytucyjny Rzeczypospolitej Polskiej w swym orzecznictwie wypowiadał się na temat możliwych ograniczeń prawa do prywatności. ${ }^{12}$

\footnotetext{
7 J. Sieńczyło-Chlabicz, Naruszenie prywatności osób publicznych przez prasę. Analiza cywilnoprawna, Kraków 2006, s. 79.

8 D. Solove, M. Rotenberg, P. Schwartz, Privacy, Information And Technology, Aspen Publishers 2006, s. 1.

9 Aksu v. Turcja, wyrok Wielkiej Izby z 15 marca 2012 r. w połączonych sprawach nr 4149/04 i 41029/04.

10 Niemietz v. Niemcy, wyrok z 16 grudnia 1992 r. w sprawie nr 13710/88.

11 Haase v. Niemcy, wyrok z 8 kwietnia 2004 r. w sprawie nr 11057/02.

12 Por. wyrok Trybunału Konstytucyjnego z 20 marca 2006 r. w sprawie K 17/05.
} 
W odróżnieniu od państw dojrzałej demokracji prawo do prywatności nie ma w Polsce wielkich tradycji. ${ }^{13}$ Do czasu uregulowania prawa do ochrony prawnej życia prywatnego na poziomie konstytucyjnym mówiono raczej o poszczególnych sferach prywatności chronionych przez prawo. Z treści art. 47 Konstytucji wynika zakaz takiego działania władzy publicznej, które przyjmowałoby postać nieuzasadnionej ingerencji w sferę stosunków rodzinnych i życia osobistego. W. Skrzydło wskazuje, że prawo określone w art. 47 Konstytucji zabrania ingerencji państwa w ustalony prawnie zakres życia człowieka, zaś w przypadku naruszenia tej sfery nakazuje państwu zapewnić ochronę. ${ }^{14} \mathrm{Na}$ państwie ciąży zatem obowiązek poszanowania praw i wolności oraz obowiązek ich ochrony. Pierwszy z nich oznacza, że władze publiczne powinny powstrzymać się od wszelkich działań mogących naruszyć gwarantowane prawa. Drugi zaś stanowi powinność podjęcia działań zabezpieczających jednostkę przed naruszeniem przysługujących jej praw przez inne podmioty. Pamiętać jednak należy, że Konstytucja gwarantuje ochronę sfery prywatności jednostki przede wszystkim w wymiarze wertykalnym, tj. wobec organów władzy publicznej i innych podmiotów publicznych. ${ }^{15}$

Ochrona prywatności nakłada się często z innymi dobrami podlegającymi ochronie prawnej. ${ }^{16}$ B. Banaszak wskazuje, że art. 47 Konstytucji jest swoistym lex generalis dla pozostałych norm konstytucyjnych dotyczących prywatności i regulujących niektóre jej aspekty. ${ }^{17}$ Inne prawa i wolności konstytucyjne mieszczące się w sferze prywatności stanowią zatem konkretyzację tego prawa. Prawo do prywatności łączy zatem z innymi konstytucyjnie gwarantowanymi prawami i wolnościami jednostki, tj. z zagwarantowanymi w art. 49 Konstytucji wolnością i ochroną tajemnicy komunikowania się, z przewidzianą w art. 50 Konstytucji nienaruszalnością mieszkania, pomieszczenia lub pojazdu, z wynikającymi z treści art. 52 Konstytucji wolnością poruszania się po terytorium Rzeczypospolitej oraz prawem wyboru miejsca zamieszkania i pobytu, a także z określonym w art. 48 Konstytucji prawem do wychowania dzieci zgodnie $\mathrm{z}$ własnymi przekonaniami. ${ }^{18}$ Ochrona życia prywatnego stanowi także, stosownie do art. 45 ust. 2 Konstytucji, jedną z przesłanek wyłączenia jawności rozprawy.

Prawo do prywatności obejmuje także autonomię informacyjną, czyli prawo do decydowania o ujawnieniu informacji o sobie i do kontroli nad tymi informacjami.

\footnotetext{
13 Przyjmuje się, że w polskiej literaturze pierwszą próbę sformułowania definicji prawa do prywatności podjął A. Kopff w artykule „Koncepcja praw do intymności i prywatności życia osobistego”. Przez prawo do ochrony życia prywatnego rozumiał on „prawo jednostki do życia swym własnym życiem układanym według własnej woli z ograniczeniem do niezbędnego minimum wszelkiej ingerencji zewnętrznej." Jako pierwszy w polskiej doktrynie argumentował za objęciem sfery życia prywatnego ochroną z art. 23 i 24 k.c. Jego koncepcja spotkała się z aprobatą przedstawicieli doktryny, jednakże za stanowiskiem tym nie podążyło orzecznictwo.

14 W. Skrzydło, Komentarz do art. 47 Konstytucji RP, LEX.

15 J. Sieńczyło-Chlabicz, Naruszenie prywatności..., op. cit., s. 71.

16 M. Pryciak, Prawo do prywatności, „Studia Erasmiana Wratislaviensia” 2010, nr 4, s. 216.

17 B. Banaszak, Komentarz do art. 47 Konstytucji RP, LEGALIS

18 Por. J. Braciak, Prawo do prywatności, op. cit., s. 135 i n.
} 
Na poziomie konstytucyjnym kwestie te reguluje art. 51 Konstytucji przewidujący ochronę danych osobowych. Stosownie do treści przepisu art. 51 ust. 2 Konstytucji władze publiczne nie mogą pozyskiwać, gromadzić i udostępniać innych informacji o obywatelach niż te, które są niezbędne w demokratycznym państwie prawnym. W kontekście ochrony prawa do prywatności trzeba powiedzieć o szczególnej kategorii danych osobowych, określanych mianem danych wrażliwych. Na gruncie prawa polskiego brak jest definicji legalnej danych wrażliwych, jednakże doktryna wskazuje, że ich katalog został określony w art. 27 ustawy z 29 sierpnia 1997 r. o ochronie danych osobowych, ${ }^{19}$ zgodnie z którym zabronione jest przetwarzanie danych ujawniających pochodzenie rasowe, etniczne, poglądy polityczne, przekonania religijne, filozoficzne, przynależność wyznaniową, partyjną lub związkową, jak również danych o stanie zdrowia, kodzie genetycznym, nałogach lub życiu seksualnym oraz dotyczących skazań, orzeczeń o ukaraniu i mandatów karnych, a także innych orzeczeń wydanych w postępowaniu sądowym lub administracyjnym. ${ }^{20}$

Na poziomie ustawodawstwa zwykłego ${ }^{21}$ ochronę prawa do prywatności przewidują przepisy k.c. Kluczową rolę w tym zakresie odegrał wyrok SN z 18 stycznia 1984 r. I CR 400/83, który stwierdza, że ,otwarty katalog dóbr osobistych (art. 23 i art. 24 k.c.) obejmuje także dobra osobiste związane ze sferą życia prywatnego, rodzinnego, ze strefą intymności. Ochrona w tym zakresie może odnosić się do wypadków ujawnienia faktów z życia osobistego i rodzinnego, nadużywania uzyskanych informacji, zbierania $\mathrm{w}$ drodze prywatnych wywiadów informacji i ocen ze sfery intymności, aby je opublikować lub w inny sposób rozgłaszać."22

Skoro nie ulega wątpliwości, że prawo do prywatności uznane zostało za dobro osobiste, należy rozważyć, jakie instrumenty prawne, umożliwiające ochronę prywatności przed nieuprawnioną ingerencją, przysługują jednostce. Ochronę dóbr osobistych można podzielić na ochronę niemajątkową i majątkową. Do tej pierwszej kategorii należeć będzie, stosownie do art. 189 k.p.c., roszczenie o ustalenie, że dane prawo osobiste - w tym przypadku prawo do prywatności - przysługuje konkretnej osobie, a także roszczenia wynikające z art. 24 § 1 k.c., czyli roszczenie prewencyjne oraz roszczenie o usunięcie skutków naruszenia. Ochrona majątkowa będzie zaś obejmowała roszczenia o zadośćuczynienie pieniężne za naruszenie dobra osobistego wynikające z art. $24 \S 1$ k.c., z art. $445 \S 1$ k.c. w zW. z art. 444 k.c. oraz $\mathrm{z}$ art. 448 k.c. Ponadto zaś osoba, której prawo do prywatności zostało naruszone,

\footnotetext{
19 Dz.U. z 2002 r. Nr 101, poz. 926.

20 J. Barta, P. Fajgielski, R. Markiewicz, Ochrona danych osobowych. Komentarz do art. 27, LEX.

21 Przepisy dotyczące prawa do prywatności znalazły się również w innych przepisach rangi ustawowej, m.in. ustawy z 6 czerwca 1997 r. Kodeks karny (Dz.U. z 1997 r. Nr 88, poz. 553), ustawy z 26 stycznia 1984 r. prawo prasowe (Dz.U. z 1984 r. Nr 5, poz. 24), ustawy z 16 kwietnia 1993 r. o zwalczaniu nieuczciwej konkurencji (Dz.U. z 2003 r. Nr 153, poz. 1503), ustawy z 18 lipca 2002 r. o świadczeniu usług drogą elektroniczną (Dz.U. z 2002 r. Nr 144, poz. 1204). 
będzie mogła domagać się zasądzenia odpowiedniej sumy pieniężnej na wskazany przez nią cel społeczny, bowiem roszczenia wynikające z art. 448 k.c. mają charakter kumulatywny. ${ }^{23} \mathrm{~W}$ przypadku, gdy wskutek naruszenia prawa do prywatności powstała szkoda majątkowa, stosownie do treści przepisu art. $24 \S 2$ k.c., poszkodowanemu przysługuje także odszkodowanie.

Nie sposób podać wyczerpującej listy działań, które mogą być uznane za naruszenie prawa do prywatności, jak też elementów składających się na to prawo, gdyż ewoluuje ono wraz z rozwojem życia społecznego i zaczyna obejmować coraz to szersze aspekty. Mimo coraz sprawniejszego funkcjonowania systemów ochrony praw człowieka i istnienia rozbudowanych systemów normatywnych, których celem jest ochrona prywatności, paradoksalnie jednostka traci współcześnie swą prywatność. Zdobycze techniczne współczesnej cywilizacji umożliwiające daleko idącą ingerencję w prywatność powodują, że częstokroć stajemy się nieświadomymi ofiarami działań naruszających naszą prywatność. ${ }^{24}$

W związku z rozwojem technologicznym obserwujemy pojawienie się nowych zagrożeń prywatności. M. Kutyłowski podkreśla, że lawinowy wzrost liczby dostępnych danych oraz coraz niższe koszty dostępu do informacji znacząco utrudniają opanowanie sytuacji pod względem ochrony prywatności. ${ }^{25}$ Rozwój technicznych środków zbierania, gromadzenia i wyszukiwania informacji o jednostkach rodzi konieczność stworzenia prawnych mechanizmów ochrony ludzkiego prawa do prywatności. W dodatku, w obliczu postępującej informatyzacji życia społecznego, konieczność ta zachodzi na poziomie globalnym, co stanowi istotną barierę w stworzeniu efektywnej regulacji.

Coraz więcej naszych indywidualnych działań społecznych ma miejsce za pośrednictwem Internetu - dzięki dynamicznemu rozwojowi obrotu elektronicznego, coraz większej ilości usług świadczonych drogą elektroniczną, a także rosnącej popularności różnego rodzaju portali społecznościowych. Niekontrolowane przetwarzanie danych przesyłanych przez Internet stwarza zagrożenia, których większość internautów nie jest świadoma. Bez wiedzy i zgody użytkowników sieci gromadzone są dane o odwiedzanych przez nich witrynach czy o lokalizacji ich komputerów. ${ }^{26}$ Pliki zwane ciasteczkami (cookies), zbierające informacje statystyczne o zachowaniach i preferencjach użytkowników sieci, są automatycznie umieszczane na komputerach użytkowników przez odwiedzane przez nich witryny internetowe. Wykorzystywane są w szczególności do umożliwienia identyfikacji użytkownika bez

23 Por. uchwała 7 sędziów SN z 9 września 2008 r. sygn. akt III CZP 31/08 (OSNC 2009/3/36).

24 A. Sakowicz, Prawnokarne gwarancje prywatności, Kraków 2006, s. 19.

25 M. Kutyłowski, Nowe perspektywy ochrony prawa do prywatności, [w:] X-lecie. Księga pamiątkowa z okazji dziesięciolecia Centrum Badań Problemów Prawnych i Ekonomicznych Komunikacji Elektronicznej i Studenckiego Koła Naukowego - Blok Prawa Komputerowego, Wrocław 2012, s. 138.

26 D. Wieszczycki, Dane osobowe w Internecie - zagrożenia i ochrona, [w:] Polska w drodze do globalnego społeczeństwa informacyjnego, Warszawa 2002, s. 84. 
konieczności wielokrotnego wprowadzania hasła oraz personalizacji witryn na potrzeby konkretnych użytkowników. ${ }^{27}$ Przepisy ustawy z 3 sierpnia 2004 r. prawo telekomunikacyjne ${ }^{28}$ zapewniają jedynie częściową ochronę, nakładając obowiązki jedynie na dostawców usług i operatorów.

Za sprawą Internetu wszystko co czynimy za jego pośrednictwem dzieje się wszędzie i natychmiast. Przesłanie informacji z jednego końca świata na drugi zajmuje ułamek sekundy. Jednostka zaś nie zawsze ma możliwość decydowania o tym, jakie dane zostaną upublicznione. Nie mamy bowiem wpływu na to, czy nasza nieruchomość zostanie upubliczniona w mapach satelitarnych dostępnych w Internecie, np. w Google StreetView. Z udogodnień technicznych coraz chętniej korzystają organy władzy publicznej. Dzięki zdjęciom satelitarnym władze niektórych stanów dysponują szczegółowymi informacjami na temat zabudowy terenu i porównują je z danymi zgłoszonymi przez podatników, by skorygować wysokość należnego podatku. ${ }^{29} \mathrm{~W}$ Arizonie Departament Zasobów Wodnych wykorzystuje je zaś do poszukiwania osób uprawiających pola bez zezwolenia na meliorację. ${ }^{30}$

Władza publiczna już gromadzi olbrzymią ilość informacji o nas w różnego rodzaju bazach danych. Urodzenie, zawarcie małżeństwa, rozwód, miejsce zamieszkania, własność nieruchomości i samochodów, uzyskiwane dochody, prowadzenie działalności gospodarczej to tylko przykładowe kategorie, które podlegają rejestracji przez państwo. Również sektor prywatny gromadzi i przetwarza różnego rodzaju dane, głównie w celach marketingowych. Elektroniczne środki płatnicze pozawalają bankom na śledzenie struktury naszych wydatków. Operatorzy systemów telefonii komórkowej dysponują danymi na temat położenia użytkownika oraz danymi billingowymi. Informacje te objęte są tajemnicą telekomunikacyjną, a ich ujawnienie poza przypadkami przewidzianymi w ustawie rodzi odpowiedzialność karną. Dostęp do nich jest jednak w każdej chwili możliwy.

Nie należy zapominać o systemach kamer CCTV (close circuit television), które w wielu wypadkach połączone są z systemem identyfikacji biometrycznej, umożliwiającej ustalenie tożsamości osób zarejestrowanych. Najnowocześniejsze systemy monitoringu pozwalają zaś na „przenikanie” przez bariery zdawałoby się nie do pokonania - jak np. ściany. ${ }^{31} \mathrm{~W}$ dzisiejszym świecie każdy może stać się inwigilatorem. Do tego celu wystarczy bowiem telefon komórkowy wyposażony w cyfrowy aparat i kamerę. Dostęp do specjalistycznych urządzeń rejestrujących obraz

27 A. Suchorzewska, Ochrona prawna systemów informatycznych wobec zagrożeń cyberterroryzmem, Warszawa 2012, s. 94.

28 Dz.U. z 2004 r. Nr 171, poz. 1800.

29 S. Garfinkel, Database Nation. The Death of Privacy in the 21st Century, O'Reilly Media 2001, s.100 i n., [za:] W. Gogłoza, Prawo do prywatności w społeczeństwie informacyjnym, tekst udostępnionyna stronie internetowej http://wgogloza.com/

30 D. E. Denning, Wojna informacyjna i bezpieczeństwo informacji, Warszawa 2002, s. 216.

31 W. Gogłoza, Prawo do prywatności..., op. cit., tekst i cytowana tam literatura. 
i dźwięk jest powszechnie możliwy dzięki coraz popularniejszym sklepom detektywistycznym, w których ofercie znajdują się minikamery, podsłuchy, lokalizatory GPS $^{32}$ i inne urządzenia umożliwiające szpiegowanie.

Pytanie, co może się stać z pozyskanymi informacjami lub danymi, gdy dostaną się w niepowołane ręce. Nawet w sytuacji, gdy dane podlegają prawnej ochronie, samo ich istnienie stwarza zagrożenie. W dynamicznie zmieniającej się rzeczywistości zadanie ustawodawcy polega na stworzeniu efektywnych mechanizmów ochrony praw i wolności. Prawo musi reagować na zmieniającą się rzeczywistość i gwarantować ochronę zarówno na płaszczyźnie wertykalnej, jak i horyzontalnej. Uzasadniony jest zatem postulat wprowadzania skutecznych metod ochrony prawnej i technicznej przed agregacją i analizą danych gromadzonych i katalogizowanych w różnego rodzaju bazach danych. Przed prawodawcą stoi zatem wielkie wyzwanie, choć nasuwają się wątpliwości, czy w ogóle możliwe jest uregulowanie tej materii.

\section{BIBLIOGRAFIA}

1. Banaszak B., Komentarz do art. 47 Konstytucji RP, LEGALIS

2. Barta J., Fajgielski P., Markiewicz R., Ochrona danych osobowych. Komentarz do art. 27, LEX

3. BeVier L.R., What Privacy Is Not, "Harvard Journal of Law \& Public Policy" 1989, no. 12.

4. Denning D.E., Wojna informacyjna i bezpieczeństwo informacji, Warszawa 2002.

5. Garfinkel S., Database Nation. The Death of Privacy in the 21st Century, O'Reilly Media 2001, [za:] Gogłoza W., Prawo do prywatności w społeczeństwie informacyjnym, tekst udostępnionyna stronie internetowej http://wgogloza.com/

6. Innes J.C., Privacy, Intimacy, and Isolation, New York-Oxford 1992, [za:] Motyka K., Prawo do prywatności i dylematy współczesnej ochrony praw człowieka, Lublin 2006.

7. Keynes E., Liberty, Property, and Privacy. Toward a Jurisprudence of Substantive Due Process, University Park 1996, [za:] Braciak J., Prawo do prywatności, Warszawa 2004.

8. Kutyłowski M., Nowe perspektywy ochrony prawa do prywatności, [w:] X-lecie. Księga pamiątkowa z okazji dziesięciolecia Centrum Badań Problemów Prawnych i Ekonomicznych Komunikacji Elektronicznej i Studenckiego Koła Naukowego - Blok Prawa Komputerowego, Wrocław 2012.

9. Motyka K., Prawo do prywatności i dylematy współczesnej ochrony praw człowieka, Lublin 2006.

10. Posner R.,The Right to Privacy, [w:] „Georgia Law Review” 12/1978.

11. Pryciak M., Prawo do prywatności, „Studia ErasmianaWratislaviensia” 2010, nr 4.

12. Puwalski M., Prawo do prywatności osób publicznych, Toruń 2003. 
13. Sakowicz A., Prawnokarne gwarancje prywatności, Kraków 2006.

14. Sieńczyło-Chlabicz J., Naruszenie prywatności osób publicznych przez prasę. Analiza cywilnoprawna, Kraków 2006.

15. Solove D., Rotenberg M., Schwartz P., Privacy, Information And Technology, Aspen Publishers 2006.

16. Suchorzewska A., Ochrona prawna systemów informatycznych wobec zagrożeń cyberterroryzmem, Warszawa 2012.

17. Thomson J.J., The Right to Privacy, "Philosophy and Public Affairs" 4/1975.

18. Skrzydło W., Komentarz do art. 47 Konstytucji RP, LEX

19. Wieszczycki D., Dane osobowe w Internecie - zagrożenia i ochrona, [w:] Polska w drodze do globalnego społeczeństwa informacyjnego, Warszawa 2002.

20. Young J.B., Privacy, Chichester 1978.

21. Ustawa z 26 stycznia 1984 r. prawo prasowe (Dz.U. z 1984 r. Nr 5, poz. 24).

22. Ustawa z 16 kwietnia 1993 r. o zwalczaniu nieuczciwej konkurencji (Dz.U. z 2003 r. Nr 153, poz. 1503).

23. Ustawa z 6 czerwca 1997 r. Kodeks karny (Dz.U. z 1997 r. Nr 88 poz. 553).

24. Ustawa z 18 lica 2002 r. o świadczeniu usług drogą elektroniczną (Dz.U. z 2002 r. Nr 144, poz. 1204).

25. Aksu v. Turcja, wyrok Wielkiej Izby z 15 marca 2012 r. w połączonych sprawach nr 4149/04 i 41029/04.

26. Niemietz v. Niemcy, wyrok z 16 grudnia 1992 r. w sprawie nr 13710/88.

27. Haase v. Niemcy, wyrok z 8 kwietnia 2004 r. w sprawie nr 11057/02.

28. Uchwała 7 sędziów SN z 9 września 2008 r. sygn. akt III CZP 31/08 (OSNC 2009/3/36).

29. Wyrok Trybunału Konstytucyjnego z 20 marca 2006 r. w sprawie K 17/05. 
THE RIGHT TO PRIVACY IN THE CONTEMPORARY WORLD

The right to protect privacy is guaranteed in the Constitution of the Republic of Poland as well as the European Convention on Human Rights. The article presents different attempts to define privacy. It discusses the challenges to privacy posed in an age of technological advances. It is vital to estimate to what extent new technologies can be a threat to the private sphere in order to provide effective pieces of legislation that govern the protection of personal data and other aspects of privacy.

Key words: privacy, the right to privacy, personal data protection 